\title{
Technopolis as the Technologized Kingdom of God
}

Fun as Technology, Technology as Religion in the 21st century. God sive Fun

Technopolis comme royaume technologisé de Dieu. L'Amusement (Fun) comme technologie, la technologie comme religion au xxi siècle. Dieu sive Fun Technopolis as the Technologised Kingdom of God. Fun as Technology, Technology as Religion in the 21st Century. God sive Fun

\section{Marina Christodoulou}

\section{(2) OpenEdition}

\section{Journals}

Electronic version

URL: http://journals.openedition.org/ceg/3019

DOI: $10.4000 /$ ceg.3019

ISSN: 2605-8359

\section{Publisher}

Presses Universitaires de Provence

Printed version

Date of publication: 26 April 2018

Number of pages: 119-132

ISBN: 979-10-320-0160-8

ISSN: 0751-4239

\section{Electronic reference}

Marina Christodoulou, «Technopolis as the Technologized Kingdom of God », Cahiers d'Études

Germaniques [Online], 74 | 2018, Online since 26 October 2019, connection on 29 November 2020

URL : http://journals.openedition.org/ceg/3019 ; DOI : https://doi.org/10.4000/ceg.3019 


\title{
Technopolis as the Technologized Kingdom of God
}

\author{
Fun as Technology, Technology as Religion \\ in the 21st century. God sive Fun
}

Marina Christodoulou

University of Klagenfurt / University of Toulouse - Jean Jaurès

\begin{abstract}
A fire broke out backstage in a theatre. The clown came out to warn the public; they thought it was a joke and applauded. He repeated it; the acclaim was even greater. I think that's just how the world will come to an end: to general applause from wits

who believe it's a joke.
\end{abstract}

(Søren Kierkegaard. Either/Or: A Fragment of Life, 122)

Neil Postman starts his book Technopoly: The Surrender of Culture to Technology (1993) ${ }^{1}$ with a quote from Paul Goodman's New Reformation: "Whether or not it draws on new scientific research, technology is a branch of moral philosophy, not of science." (Postman 1993: motto; Goodman 2010: 40). I would extend Postman's Technopoly to Technopolis, to give it more of a presence in time and space. Hence, I will use the term Technopoly when I am referring to Postman; the term Technopolis is my own.

In his book From Faith to Fun: The Secularisation of Humour, Russel Heddendorf argues that humour is a technology (Heddendorf 2009: 32-34), as it is understood and theorized by Neil Postman in Technopoly. Russel Heddendorf also argues that "Technopoly" is a term correlated with Wittgenstein's use of the term "worldview" (Weltanschauung) (Heddendorf 2009: 11).

I would like to draw on these thoughts to propose that Technopoly (or Technopolis) could be the secularized Kingdom of God, namely that Technology is the Religion of the 21st century, and that Fun is a paradigm of such a Technology / Technique. God is yet another technique or Technology of and in Technopoly.

1. Another important book discussing Technology, from a sociological and literary perspective, is Bruno Latour's Aramis or The Love of Technology (1996). 
The godless individual in the 21st century, I will argue, is as much a believer as the faithful in the Sacred Religion (term used in opposition to Secular or rather Technological or Technologized Religion, which is Fun). He believes in Fun (as a post-modern form of pleasure), as much as the believer believes, or more accurately, believed in God. In the 21st century, the faithful in Sacred Religion believes in a fun God, as opposed to the serious God of the past. Fun is turning into the Technologized Religion for all; for the faithful in Godly / Sacred Religion, as well for as the unfaithful. Fun (pleasure, humour) is the definitive qualia of 21st century pleasure. The mechanics of Fun make it absolutely functional for controlling people; as Aldous Huxley wrote in Brave New World, people "are controlled by inflicting pleasure" (cited in Heddendorf 2009: 158). Now, indulging in pleasure is having Fun. In the 21st century, nobody is unfaithful, nobody disputes God, because God has been manufactured into Fun. We are living in the most religious century of all.

The commodity of God, now inextricably blended into work and leisure ethics and culture, is as unavoidable as survival. You don't work, you don't survive, you don't exist. You work, you are entitled to leisure, or free time - the time ("busy-time") when you are busy is work. The free time of leisure ("fun-time") is a time for fun (pleasure). The time dedicated to Fun is culturally (capitalistically) pre-defined; no moment is actually free, each moment that is sold as free is to be bought with Work Time tokens -which is money. Believe is Enjoy. Happiness, achieved through pleasure, and pleasure through Fun, and Life as Play, is the recipe for Teleology in the 21st century.

The Technological God (Fun), as the Sacred God before him, is sovereignty's technique or a social "mode of release" ${ }^{2}$ : demonstrations, marches, petitions, freedom of speech, citizen and human rights vindications, are "modes of release", so that the next day, feeling relieved and released that you are working for a better life and a better world, you can wake up cheerfully to walk to your workplace, feeling it will change because of your marching, or your petition, or your speech, or the mass you attended, or the prayer you said yesterday. Thus life continues unchanging, through postponing hope; the tension of the tragedy is always released (lysis) in catharsis: refreshment for the next day of work. Art, especially cinema, (namely, simulated life) follows the same cathartic principles as real life. Thus, you can keep coping, and hoping in the meantime is of much help. Religion, Art, Science, Therapy, and Technology are all technologies used to market life, sell it or lend it, and humans are buying it back. Fun is free to produce, and expensive to buy. 


\section{A History of Culture and Religion through Technology: The Rise of Technopoly}

The God of the Bible is a different God from the one in the Torah, or the Koran, and God in a printed Bible is different from God in a digital Bible, or from the God in spoken words; God in Greek is different from God in French, and God as chanted by a Priest is different from God that people read about in books. God becomes different when worshipped at home, in the Lutheran sense, compared to when worshipped in Church. Greta Garbo would not be Greta Garbo in colour. Can you even think of Greta Garbo other than in black and white? Mathematics done on paper are different from those done mentally or on a computer. No matter how much you improve your mathematics on paper you will not simultaneously improve your mathematics on a computer at the same pace; you will only improve them by doing mathematics on computer. The same way that you don't improve much in anything else by solving crosswords, except at solving crosswords.

Similarly, no matter how societies believed in (a) God during the Sacred Religion era, their belief is never in the same God in the era of Technologized Religion. The meaning of the term God has changed. It is impossible to be the same God even if the arrangement of letters remains the same. Every term is in a process of becoming. We do not believe in the same God as people did in a previous era, or as other cultures do, or even as our neighbours do, or ourselves in the past.

In this era, as culture has evolved, the God we believe in, - since there is a word "God", it will never be completely eradicated, and will always carry some meaning - is close to being synonymous with the term Fun. Fun is Religion; Fun is God. Is Religion Fun, and is God Fun? Religions themselves are trying to embrace Fun in order not to lose believers: they sing in churches, they are becoming more tolerant, they advise caring for your body, they are becoming more "cool": they are more accepting of marriages between homosexuals, women wearing whatever, sex before marriage, etc.

When we say God, the word carries and will still carry for a long time to come, the historical bias of the past meaning of the Sacred Religion. So, when we say God, the word is biased, and does not in any way mean Fun, but when we say Fun the word does connote God, the new Technologized Religion. As Nietzsche wrote, "I am afraid we're not rid of God because we still believe in grammar..." (Nietzsche 1997: 21). ${ }^{3}$ Grammar is one of the primary human technologies, along with language.

The medium or the technology of the clock, for instance, has redefined time (Postman 2006: 11-12). The medium of the papyrus, then paper, and then the digital screen, have redefined speech, thought and language. Different transportation media have redefined distance and space, and relationships, therefore physical

3. Other translations replace "believe" with "have faith." 
and ethical culture. The media of virtual and digital reality have redefined God as Fun. In pre-virtuality eras, God was Virtue, Nation, Survival, Safety, Success, Happiness, Health, Love, Immortality. God is still all these, because language, as mentioned earlier, has embedded a tradition and a habit of meanings in this particular word, but now God is something new, too: Fun; and as something new it becomes more prevalent, next to the other things He is. Fun is a thing of our times. And every new trend is greeted in godly ways. Fun is the new meaning of God (God sive Fun). ${ }^{4}$

The medium forms the message, just as the form or the morphology of a text forms its meaning. ${ }^{5}$ In other words, as Neil Postman says, inspired by the Myth

4. For this concept of God sive Fun, see also W. V. Quine (1951: 41) "Main Trends in Recent Philosophy: Two Dogmas of Empiricism": "Physical objects are conceptually imported into the situation as convenient intermediaries - not by definition in terms of experience, but simply as irreducible posits comparable, epistemologically, to the gods of Homer. [...] But in the point of epistemological footing, the physical objects and the gods differ only in degree and not in kind. Both sorts of entities enter our conception only as cultural posits." See also Muriel Rukeyser's verse: "The universe is made of stories, not of atoms." From the poem "The Speed of Darkness", originally published in The Speed of Darkness. I also should note, that I understand fun in a broader sense: as an evolution of pleasure, as a path to happiness. Happiness has been the moral goal of humanity for many centuries, including the current one. If you don't have fun, are you immoral? Kind of. As for Transcendence, what becomes of it? What about this human experience of transcendence? I think we will not need it. Bio-chemicals and other chemicals (pharmaceutical, as well as all the other chemicals found everywhere) are activated with Fun, such as adrenaline, dopamine (video games, movies, alcohol, drugs, legal and illegal, etc.). See for example Robert S. De Ropp's book Drugs and the mind; Sally Freeman's Drugs and Civilization; D.C.A. Hillman's The Chemical Muse: Drug Use and the Roots of Western Civilization; Terence McKenna's Food of the Gods: The Search for the Original Tree of Knowledge. A Radical History of Plants, Drugs, and Human Evolution; etc. Finally, for the abolishment of the sacred order in current culture, one could see Sacred Order/Social Order. Volume II: The Crisis of the Officer Class: The Death of the Tragic Sensibility. (Philip Rieff 2007).

5. See, for example, the case of the Russian Formalists that theorized this statement. See also, Postman (2006: 8-10): "[T]he clearest way to see through a culture is to attend to its tools for conversation. [...] In studying the Bible as a young man, [...] I wondered then, as so many others have, as to why the God of these people would have included instructions on how they were to symbolize, or not symbolize, their experience. It is a strange injunction to include as part of an ethical system unless its author assumed a connection between forms of human communication and the quality of a culture. [...] The God of the Jews was to exist in the Word and through the Word, an unprecedented conception requiring the highest order of abstract thinking. Iconography thus became blasphemy so that a new kind of God could enter a culture. $[\ldots]$

Speech, of course, is the primal and indispensable medium. It made us human, keeps us human, and in fact defines what human means. This is not to say that if there were no other means of communication all humans would find it equally convenient to speak about the same things in the same way. We know enough about language to understand that variations in the structures of languages will result in variations in what may be called "world view". How people think about time and space, and about things and processes, will be greatly influenced by the grammatical features of their language. [...] For although culture is a creation of speech, it is recreated anew by every medium of communication -from painting to hieroglyphs to the alphabet to television. Each medium, like language itself, makes possible a unique mode of discourse by providing a new orientation for thought, for expression, for sensibility. Which, of course, is what McLuhan meant in saying the medium is the message. His aphorism, however, is in need of amendment because, as it stands, it may lead one to confuse a message with a metaphor. [...] As Ernst 
of Thamus (from Plato's Phaedrus ${ }^{6}$ ), the medium, or the technology, technique, or tool, is not neutral:

So much for Thamus' error of omission. There is another omission worthy of note, but it is no error. Thamus simply takes for granted - and therefore does not feel it necessary to say - that writing is not a neutral technology whose good or harm depends on the uses made of it. He knows that the uses made of any technology are largely determined by the structure of the technology itself - that is, that its functions follow from its form. This is why Thamus is concerned not with what people will write; he is concerned that people will write. (Postman 1993: 7)

Technologies change "habits of thought" (Postman 1993: 12) into other habits of thought. Even the slightest technological change or introduction, for example assigning grades to school (ibid.: 12-13), introducing matches to an African tribe (ibid.: 27-8), or the invention of the clock (ibid.: 14-15), will result in cornerstone changes in the "habits of thought" of a person and a society. It seems that there is "an ideological bias" "in every tool", "a predisposition to construct the world as one thing rather than another, to value one thing over another, to amplify one sense or skill or attitude more loudly than another" (ibid.: 13):

This is what Marshall McLuhan meant by his famous aphorism "The medium is the message". This is what Marx meant when he said, "Technology discloses man's mode of dealing with nature" and creates the "conditions of intercourse" by which we relate to each other. It is what Wittgenstein meant when, in referring to our most fundamental technology, he said that language is not merely a vehicle of thought but also the driver. And it is what Thamus wished the inventor Theuth to see. This is, in short, an ancient and persistent piece of wisdom, perhaps most simply expressed in the old adage that, to a man with a hammer, everything looks like a nail. (Postman 1993: 13-14)

This is yet another principle of technological change we may infer from the judgment of Thamus: new technologies compete with old ones - for time, for attention, for money, for prestige, but mostly for dominance of their world-view. This competition is implicit once we acknowledge that a medium contains an ideological bias. And it is a fierce competition, as only ideological competitions can be. [...] When media make war against each other, it is a case of world-views in collision. (ibid.: 16)

New technologies alter the structure of our interests: the things we think about. They alter the character of our symbols: the things we think with. And they alter the nature of community: the arena in which thoughts develop. (ibid.: 20)

There have been many attempts to classify culture according to the technologies of each era (ibid.: 22). Postman proposes a taxonomy of three stages or three types of culture. Following these taxonomies, one can at the same time engage in a history of religious belief, or the changing concept of God as dictated by technology.

Cassirer remarked: 'Physical reality seems to recede in proportion as man's symbolic activity advances. Instead of dealing with the things themselves man is in a sense constantly conversing with himself. He has so enveloped himself in linguistic forms, in artistic images, in mythical symbols or religious rites that he cannot see or know anything except by the interposition of [an] artificial medium."”

6. For an introduction to the myth, see Postman (1993: 7-8). The whole myth can be found in Plato, Phaedrus 274b-278d. 
First, the tool-using cultures, then the technocracy, and currently the Technopoly. In tool-using cultures, everything derives from God, all knowledge and authorization. This is a theocratic era and all the tools are designed to serve towards and subordinate to God's will. But of course, there are instances -and Postman cites such examples- where tools "have a way of intruding on even the most unified set of cultural beliefs. There are limits to the power of both theology and metaphysics, and technology has business to do which sometimes cannot be stayed by any force." (ibid.: 26) For example, the matches introduced in an African tribe and how they changed their sexual habits, and mounted shock combat (ibid.: 26).

Second came the technocracy stage or culture: "In a technocracy, tools play a central role in the thought-world of the culture. [...] Tools are not integrated into the culture; they attack the culture. They bid to become the culture." (ibid.: 28) Examples include the alphabet, ${ }^{7}$ the mechanical clock, the "printing press with movable type", and the telescope. Each of them attacked a habit world: the perception of time, the oral tradition, and the Christian teleology, respectively (ibid.: 28-9). However, theology remained a theology of God, and even Copernicus and Kepler conducted their science independently of theological principles, without any effort to shake them. Descartes, too, although talking about a mechanistic universe, deduced it from properties of God. Science was more of an amateur's game than something to be taken seriously. At times scientists were even unsatisfied with the utterances of their science because they collided with or did not promote the utterance of Scripture. Thus the 18th and 19th century were still completely theocratic. Galileo's original contribution to the world was not so much his discoveries in science and astronomy, but that he set up Science face-to-face with Religion. He was the first scientist to take science seriously and to question religion's principles from the scientist's position (worldview). This is why Galileo was prosecuted but not Copernicus or Kepler. Newton continued and integrated the establishment of Science. But all of them were, according to Postman, men of tool-using cultures that laid the foundations of technocracy (ibid.: 35). The first technocrat, long before the rise of technocracy, again according to Postman, was Francis Bacon (1561). He saw the connection "between science and the improvement of the human condition", which formed the main principle of technocracy (ibid.: 35). He introduced the utilitarian side of science, and replaced Truth with Progress and Power, while also linking invention with progress (ibid.: 36). Technocracy coincided with the Industrial Revolution; it is Bacon-inspired and the mentality of modernism. Knowledge became power, so humanity was able to progress, and the life of each human being became meaningful (ibid.: 38). Still, "[i]t is untrue to say

7. See Postman (2006: 12-13, and 15). I quote from page 15: "Our conversations about nature and about ourselves are conducted in whatever 'languages' we find it possible and convenient to employ. We do not see nature or intelligence or human motivation or ideology as 'it' is but only as our languages are. And our languages are our media. Our media are our metaphors. Our metaphors create the content of our culture." 
that along the way God died" (ibid.). As Alfred North Whitehead summed it up, "the greatest invention of the nineteenth century was the idea of invention itself" (ibid.: 42). Two further characteristics of technocracy are, first, the relief of "what Tocqueville called "the disease of work", and, second, "an increased respect for the average person, whose potential and even convenience became a matter of compelling political interest and urgent social policy" (ibid.: 44). In technocracy, people were still able to hold onto their traditional beliefs and habits of thought, especially regarding beliefs in the Sacred Religion, because technology had not yet invaded the moral and ethical level of human culture. Technopoly came to do so.

So, the third cultural taxonomy, according to Postman, is Technopoly:

With the rise of Technopoly, one of those thought-worlds disappears. Technopoly eliminates alternatives to itself in precisely the way Aldous Huxley outlined in Brave New World. It does not make them illegal. It does not make them immoral. It does not even make them unpopular. It makes them invisible and therefore irrelevant. And it does so by redefining what we mean by religion, by art, by family, by politics, by history, by truth, by privacy, by intelligence, so that our definitions fit its new requirements. Technopoly, in other words, is totalitarian technocracy. (Postman 1993: 48)

Technopoly is characterized by "a technological theology" (Postman 1993: 50). Its origins are to be found much earlier than its flowering, and Postman searches for them in different places and situations, as he does for the origins of Technocracy. The thought-world of Technopoly is the thought-world of the Technologized Kingdom of God. "[T] he primary, if not the only, goal of human labor and thought is efficiency; [...] the affairs of citizens are best guided and conducted by experts. [...] [T]echnique of any kind can do our thinking for us, which is among the basic principles of Technopoly." (Postman 1993; 51-52) What distinguishes Technopoly from Technocracy and gives it its definition is "the submission of all forms of cultural life to the sovereignty of technique and technology" (ibid.: 52).

I would sum up Postman's taxonomy thus: The sovereignty of the Sacred God or the Sacred Religion is provided with fertile ground in the tool-using culture; the sovereignty of the Humanistic God named Progress and Invention, and the rise of information-production-and-consumption is given ground to exist in Technocracy; and the sovereignty of the Technological God or the Technological Religion is flourishing because of Technopoly. Technopoly has the unique ability of providing a "technological alternative" to "every Old World belief, habit, or tradition":

To prayer, the alternative is penicillin; to family roots, the alternative is mobility; to reading, the alternative is television; to restraint, the alternative is immediate gratification; to sin, the alternative is psychotherapy; to political ideology, the alternative is popular appeal established through scientific polling. There is even an alternative to the painful riddle of death, as Freud called it. The riddle may be postponed through longer life, and then perhaps solved altogether by cryogenics.

[...] [0]ld sources of belief came under siege. Nietzsche announced that God was dead. Darwin didn't go as far but did make it clear that, if we were children of God, we had come to be so through a much longer and less dignified route than we had imagined, and that in the process we had picked up some strange and unseemly relatives. [...] Amid the 
conceptual debris, there remained one sure thing to believe in - technology. Whatever else may be denied or compromised, it is clear that airplanes do fly, antibiotics do cure, radios do speak, and, as we know now, computers do calculate and never make mistakes - only faulty humans do (which is what Frederick Taylor was trying to tell us all along). (Postman 1993: 54)

In other words, for a new tool, medium, technique, or technology to flourish or to be used as such, the milieu of the culture and the worldview or the thinking environment has to change in order to be fit and welcoming for its use, or even render the tool as necessary.

The only belief left in Technopoly is in Technology, and one of these technologies is Fun. The belief in technology is as was the belief in God: we are ready to believe anything coming from Technology, as we did from God. As George Bernard Shaw already observed, and cited by Postman, "the average person today is about as credulous as was the average person in the Middle Ages. In the Middle Ages, people believed in the authority of their religion, no matter what. Today, we believe in the authority of our science, no matter what." (ibid.: 57-8) Moreover, "[w]e believe because there is no reason not to believe. [...] [T]he ways of technology, like the ways of God, are awesome and mysterious." (ibid.: 58) In other words, while everything used to be a hermeneutics of theology, it gave way to a hermeneutics of science and technology.

Here are two last attempts by Postman to complete the definition of Technopoly, which are very useful in showing the new type of ground that this century's Secular or Technological Religion has started to flourish in. One of the definitions is:

\footnotetext{
Indeed, one way of defining a Technopoly is to say that its information immune system is inoperable. Technopoly is a form of cultural AIDS, which I here use as an acronym for Anti-Information Deficiency Syndrome. This is why it is possible to say almost anything without contradiction provided you begin your utterance with the words "A study has shown ..." or "Scientists now tell us that ... ." (Postman 1993: 63)
}

In the era of Sacred Religion, you could say almost anything provided you began your utterance with the words "As the Bible says..." or "as this or that holy book (as approved by the Ecumenical Council) says..."

The rise of the information-production-and-consumption technologies brings with it new ideas and cultural traits, such as individuality, privacy, and public discourse (Postman 1993: 66-7). There are many stages of the rise of information (ibid.: 67-9): printing, telegraph, penny press, photography, broadcasting, and computer technology. The other dimension or characteristic of Technopoly is information production and consumption. This leads to boredom, a kind of metaphysical boredom. The amount of information is vast; it is information for information (Postman 1993: 59-61, 70).

Alternatively, it could be said that Technopoly is the Secularized or rather the Technological Kingdom of the Archive. Once the Sacred God served as the eternal, never-ending memory capacity, keeper of "toute la mémoire du monde" as Alain Resnais called a short film on the libraries humans have invented to store and archive everything about them. Derrida also wrote an essay entitled 
"Archive Fever", which I would connect to the derrridean "signature”. The human needs to archive every human signature. And Technology is the 21st century eternal, never-ending-memory-capacity Drive (which is God) where all the signatures are stored.

Another definition of Technopoly by Postman, is:

Technopoly is a state of culture. It is also a state of mind. It consists in the deification of technology, which means that the culture seeks its authorization in technology, finds its satisfactions in technology, and takes its orders from technology. (Postman 1993: 71) In Technopoly, the delusion is sanctified by our granting inordinate prestige to experts who are armed with sophisticated technical machinery. Shaw once remarked that all professions are conspiracies against the laity. I would go further: in Technopoly, all experts are invested with the charisma of priestliness. Some of our priest-experts are called psychiatrists, some psychologists, some sociologists, some statisticians. The god they serve does not speak of righteousness or goodness or mercy or grace. Their god speaks of efficiency, precision, objectivity. And that is why such concepts as sin and evil disappear in Technopoly. They come from a moral universe that is irrelevant to the theology of expertise. [...] (ibid.: 90)

If one replaces Technopoly with God in the above quotation, then the quotation would refer to the Sacred Religion era.

\title{
A Short Parenthesis on Canguilhem-Simondon-Stiegler and the Technics
}

During the lectures at the Collège philosophique that were later published as La connaissance de la vie (1952), Georges Canguilhem talks about the machine and the organism, referring to Bergson as one of the very few (at the time) French philosophers "to have considered mechanical invention as a biological function" (Canguilhem 2008: 174, n. 64). Canguilhem theorizes that through technology humans create their milieu. Therefore, Nature is not the only milieu. His student, Gilbert Simondon, through the notion of "associated milieus", extended the theory of Canguilhem. Simondon, as well, considers the dual sacred (sacralité) and technology (technicité):

\begin{abstract}
Technology creates a world. Its impact is cosmic, like that of the sacred. Like the sacred experience, it organizes this world by creating centres within it, privileged points and moments. The central figure in ancient thought also has an analogue in the world of technology. "the high priest who performs these new rites," writes Simondon, "is the man in the white coat; his creed is Research. Like the priest, he is ascetic and sometimes singular". (Pascal Chabot 2013: 139, quotes from Simondon's Psycho-sociologie de la technicité)
\end{abstract}

In a letter to Derrida, while contemplating the sacred and technology, he introduces the concept of the 'technoaesthetic'. ${ }^{8}$ There he expresses, as Pascal Chabot sums it up:

8. Papiers du Collège International de Philosophie, no. 12, 1992 ("Sur la techno-esthétique et Réflexions préalables à une refonte de l'enseignement”). Reference from Pascal Chabot (2013: 141 n.11). 
his taste for objects and situations that combine elements of nature with human activity: a musical instrument, a boat blown by the wind. He perceives beauty in a tool adapted to its function. The gesture of loosening a jammed screw can be 'orgasmic'. (ibid.: 141)

In general, for Simondon, what links religion and technology is the fact that they are both what came to be the phase of culture after magic, and together they form a unity that results in the evolution of the central figure of ancient thought to the first subject, which is the priest. In the "magical unity", no subjects or objects (artefacts) exist, the humans are simply living in their given natural environment. It is technology that brings the objects (artefacts) to the first subjects of the divine and the priest. ${ }^{9}$

At last, on a relevant line to Simondon, for Stiegler ${ }^{10}$ the human is a product of technology apart / except from nature and biology. ${ }^{11}$

\section{The Technological God of the 21st Century: The Oppression of Pleasure and God's Technology of Fun}

(The concept of) God still reigns, and will always; it is only its meaning that has been displaced. What changes God's meaning, as well as all the other meanings of concepts or ideas, are the media, tools, or technologies used by humans. Just as the very first, primitive, and prototype tool, which is the hand with the human patent of the thumb, changed primates to hominoids and the hominoids to humans, so evolution continues with the tools manufactured by hands (Postman's tool-culture stage), then tools manufactured by other tools (Postman's Technocracy) and now tools manufactured through an intelligence that has been manufactured, too. The latter is Postman's Technopoly, as I would describe it, adding to his description.

Technocracy brought "an increased respect for the average person" (Postman 1993: 44). Because anyone can handle a machine and everyone must have the embedded illusion that he is special, since he can handle machines; just like in theocracy, everyone felt special as a child and a creation of God. In our century or Technopoly, anyone can have Fun or is entitled to the Right of having Fun, therefore each human feels special, again.

Work in ancient Greek is Ponos, which is a God, and means toil or labor, and its genealogy shows that it is something not pleasant. He is the child of Eris, which is discord, and his siblings are Algos, which means pain; Lethe, which means oblivion or concealment; Limos, which means starvation; and Horkos,

9. See part iii of Du mode d'existence des objets techniques [On the Mode of Existence of Technical Objects] (1958).

10. See Stiegler's three volume work Technics and Time $(1998 ; 2009 ; 2011)$ [La technique et le temps (1994; 1996; 2001)]. See also, Christina Howells, Gerald Moore (eds.) (2013) Stiegler and Technics.

11. See also, Scott Campbell, Paul W. Bruno (eds.) (2013) The Science, Politics, and Ontology of LifePhilosophy, where life-philosophy (Lebensphilosophie) is viewed from a technological point of view and where the technological life dominates the biological and the historical one. 
which means oath. In Modern Greek, Ponos has changed to mean Pain. In Latin "work" was Labor, which means toil, exertion, effort, and it is also used to mean childbirth. In those cultures, work was a burden, something that if you are not in need or forced to do, you'd rather not do. God then blessed work, and he was to be blessed and to bless when people were not at work, which is once a week on a specific day, in religious celebrations, or before, during breaks, and after work. Fun is only possible when opposed to Ponos, or work, and it is outside work. Even more extremely, people are now encouraged to have Fun even at work. As people were encouraged to behave according to God and have God in mind while working, now people are encouraged to have in mind and behave according to the Fun Principle. Anything must become Fun to do, even if it is work. Outside work is the ultimate Fun, and in case you do not have Fun working, you are excused, but if you do not have Fun outside work, then you are at least mentally ill.

Fun is one of the technologies of Technopoly and Technopolis. It might also be a fourth stage (outside of Postman's theory), or a substage of stage (taxonomy) three: the Polis of Fun, or Funpoly/-is. It is the stage of the sovereignty of information and fun-consumption.

There is a shift from seriousness to Fun, which might have been triggered by the technology of television, as Postman observes (Postman 2006: 29). Television is one of "the technological distractions made possible by the electric plug" (ibid.: 156). Such technological distractions substituted thinking with laughing, and this is not quite the problem. The problem is that people do not know why they laugh or what they laugh about, and why they have Fun and what they have Fun with; it is a distraction with no root, nearly a mechanical one. ${ }^{12}$

\begin{abstract}
It's important to note here the difference between fun as action and fun as attitude. [...] Fun becomes attitudinal when such activity becomes the goal of fun-seeking. Fun is sought not because of the sense of freedom it provides, but because it is prohibited and exciting in itself. Fun is then no longer therapeutic. When fun dominates our thinking it needs no justification; it becomes its own justification. [...] In a culture of fun, Garfield becomes a comic hero who leers at us from the rear window of a passing auto and encourages us to have "some fun now." (Heddendorf 2009: 123-4)
\end{abstract}

God is taken in a funny way, and Fun is taken seriously. This is a symptom that confirms that Fun is the new God. Technology is taken extremely seriously, and of all the technologies, it is Fun which is also taken seriously; Technology is the Religion of the 21 st century.

Paradoxically, then, fun must be taken seriously. It must be understood how fun structures the secular world. It's important to consider the broader implications of fun, to see it as dysfunctional when it has harmful effects on others or on cultural values. (Heddendorf 2009: 143)

12. See Postman (2006: 163): "For in the end, he was trying to tell us that what afflicted the people in Brave New World was not that they were laughing instead of thinking, but that they did not know what they were laughing about and why they had stopped thinking." 
I believe I am not mistaken in saying that Christianity is a demanding and serious religion. When it is delivered as easy and amusing, it is another kind of religion altogether. (Postman 2006: 121)

Russel Heddendorf has some additional important observations relevant to what I am discussing here:

Cultures define the sacred in different ways at different times. Indeed, in modern times, something as secular as science may be given sacred meaning to counteract the apparent meaninglessness of a world without it. [...] Berger's definition of the sacred includes "something extraordinary and potentially dangerous," some sense of uncertainty or threat. This notion of the sacred seems less consistent with therapy and more with the idea of fun which suggests excitement, escape from the mundane and even deviance. While the therapeutic encouraged happiness in daily life through adjustment to it, fun implies happiness is found by escaping from it. There is enough unpredictability in fun to provide a thrill and often a sense of awe. As an expression of the sacred, fun is on the edge of everyday life, not completely in it and certainly not of it. (Heddendorf 2009: 168-169)

As Huxley observed, people are not controlled by being subjected to pain, as Orwell thought, they are controlled by "inflicting pleasure" (Postman 2006: xx) and this craving for pleasure, or for what they like, makes them vulnerable to distractions. They crave distractions as long as they are pleasurable. This craving imprisons them. People "love their oppression" and "adore the technologies" (Postman 2006: xix): these are two elements that both serve as cause and effect: they love their oppression because they adore their technologies, and they adore their technologies because they love their oppression, because it is an oppression of pleasure. Even though this pleasure undoes "their capacities to think" (ibid.); it doesn't matter if they think or not, as long as they experience pleasure, and more specifically, as long as they have Fun. Nobody has to ban thinking, as Orwell feared; people will abandon anything as long as it gives them pleasure. Fun is the new opium of the masses. It works as God did, that's why Fun is God, or the new God. And Fun can intrigue the non-believers in the Sacred God, as much as the believers. Everybody believes in Fun, because it is the new meaning of life; no need to create a metaphysical universe to place God inside, since Fun can survive and thrive in a godless environment, as much as in a theocratic one, because it is God without carrying the biases associated with the name "God". It can do whatever God can do, it can affect people in the same ways, without any spiritual or metaphysical narratives, and especially - and this is its greatest success - it can be God without imposing fear and pain. It only imposes pleasure. Fun's scriptures are technologies that inflict pleasure. People embrace it much more easily, and feel that it is their right to have a culture that is a "burlesque" (Postman 2006: 155), than a culture that is a "prison" (ibid.), which they would feel and felt during the reign of the Sacred God as their obligation to embrace. 


\section{Bibliography}

Campbell, Scott and Paul W. Bruno (eds.) (2013) The Science, Politics, and Ontology of Life-Philosophy. Bloomsbury.

Canguilhem, Gilbert (2008) Knowledge of Life. Stefanos Geroulanos and Daniela Ginsburg (trans.). Paola Marrati \& Todd Meyers (eds). New York: Fordham University Press, 2008. (Translation of Canguilhem, Gilbert (1952) La connaissance de la vie. Paris: Vrin.)

Chabot, Pascal (2013) The Philosophy of Simondon: Between Technology and Individuation. Graeme Kirkpatrick \&t Aliza Krefetz (trans.). Bloomsbury.

Goodman, Paul (2010) The New Reformation: Notes of a Neolithic Conservative. Introduction by Michael C. Fisher. Oakland, CA: PM Press.

Heddendorf, Russell (2009) From Faith to Fun: The Secularisation of Humour. Cambridge: Lutterworth Press.

Howells, Christina and Gerald Moore (eds.) (2013) Stiegler and Technics. Edinburgh: Edinburgh University Press.

Kierkegaard, Søren (2004) [1843] Either/Or: A Fragment of Life. Victor Eremita (ed.). Abridged, Translated and with an Introduction and Notes by Alastair Hannay. UK: Penguin Books.

Latour, Bruno (1996) Aramis or The Love of Technology. Catherine Porter (trans.). London: Harvard University Press.

Nietzsche, Friedrich (1997) [1889] Twilight of the Idols. Or, How to Philosophize with the Hammer. Richard Polt (trans.). Introduction by Tracy Strong. Indianapolis: Hackett Publishing Company.

Postman, Neil (1993) Technopoly: The Surrender of Culture to Technology. New York: Vintage Books.

Postman, Neil (2006) Amusing Ourselves to Death: Public Discourse in the Age of Show Business. New York: Penguin Books.

Quine, Willard Van Orman (1951) "Main Trends in Recent Philosophy: Two Dogmas of Empiricism”, The Philosophical Review vol. 60 n.1, p. 20-43. [www.jstor.org/stable/2181906].

Rieff, Philip (1966) The Triumph of the Therapeutic; Uses of Faith after Freud. New York: Harper \&t Row.

Rieff, Philip (2007) Sacred Order/Social Order. Volume II: The Crisis of the Officer Class: The Death of the Tragic Sensibility. Introduction by Alan Woolfolk. London: University of Virginia Press.

Rukeyser, Muriel (1968) "The Speed of Darkness", in The Speed of Darkness.

Simondon, Gilbert (1958) Du mode d'existence des objets techniques. Paris: Aubier.

Simondon, Gilbert (1992) "Sur la techno-esthétique et Réflexions préalables à une refonte de l'enseignement", Papiers du Collège International de Philosophie 12. [http://www.ciph.org/spip.php?page=publicationsttid_ rubrique $=8$ tannee $=39$ ] . 
Stiegler, Bernard (1998) Technics and Time, 1: The fault of Epimetheus. Richard Beardsworth and George Colllins (trans.). Stanford: Stanford University Press.

Stiegler, Bernard (2009) Technics and Time, 2: Disorientation. Stephen Barker (trans.). Stanford: Stanford University Press.

Stiegler, Bernard (2011) Technics and Time, 3: Cinematic Time and the Question of Malaise. Stephen Barker (trans.). Stanford: Stanford University Press.

Wittgenstein, Ludwig, Georg Henrik von Wright and Heikki Nyman (eds.) (1998; Revised Edition) Culture and Value: A Selection from the Posthumous Remains. Alois Pichler (Revised edition of the text). Peter Winch (trans.). Oxford: Blackwell. 